\title{
All is not Lost. Italian Archives and Libraries in the Second World War
}

\author{
Flavia Bruni
}

Immediately after the Liberation, the Allied commission for Monuments, Fine Arts and Archives [MFA\&A] published a report on the situation of the Italian archives. ${ }^{1}$ A short time later, a volume published by the Directorate-General of Academies and Libraries provided an exhaustive report to the Ministry of Education on the damage and losses suffered by Italian libraries during the second world war. This was followed in 1953 by another volume on the restoration of libraries carried out after the end of the war. ${ }^{2}$ These volumes are an excellent starting point for any study on the impact of the second world war on the Italian documentary and library heritage.

The two volumes on libraries provided accurate figures on the condition of collections and buildings and on the costs of reconstruction and restoration of Italian libraries. After an introduction on the Italian wartime plans for preservation, ${ }^{3}$ a chapter lists and analyses carefully the most relevant causes of damage for books and buildings: bullets, bombs, aerial bombs, mines and other accidents (ills. 23.1 and 23.2). ${ }^{4}$

1 Commission for Monuments, Fine Arts and Archives, Rapporto finale sugli Archivi (Rome: Istituto Poligrafico dello Stato, 1946), available online: <http://www.icar.beniculturali.it/ biblio/_view_volume.asp?ID_VOLUME=27 $>$. All online resources quoted in this article were last consulted on 31 August 2015. I am grateful to Jan L. Alessandrini, Anna Manfron, Alberto Petrucciani and Andrew Pettegree for their suggestions on this chapter.

2 Italy. Ministero della Pubblica Istruzione, Direzione Generale Accademie e Biblioteche, $L a$ ricostruzione delle biblioteche italiane dopo la guerra 1940-45. I. I danni and II. La ricostruzione (Rome: Ufficio Studi e Pubblicazioni, Fratelli Palombi, [1949-1953]). The two volumes on libraries were edited by Ettore Apollonj and Alda Angelini with the help of Tommaso Bozza for the first one, and Alberto Spina for the second: see Alberto Petrucciani, 'Le biblioteche italiane durante la guerra: i servizi al pubblico', in Andrea Capaccioni, Andrea Paoli and Ruggero Ranieri (eds.), Le biblioteche e gli archivi durante la seconda guerra mondiale. Il caso italiano (Bologna: Pendragon, 2007), pp. 99-141, note 3, p. 100.

3 La ricostruzione delle biblioteche italiane dopo la guerra 1940-45. I. I danni, 'Misure preventive per la tutela del materiale librario', pp. 11-18.

4 Ibid., 'I danni di guerra alle biblioteche e loro cause', pp. 19-26. A similar analysis is also available for archives in the Rapporto finale sugli Archivi, pp. 23-28. 


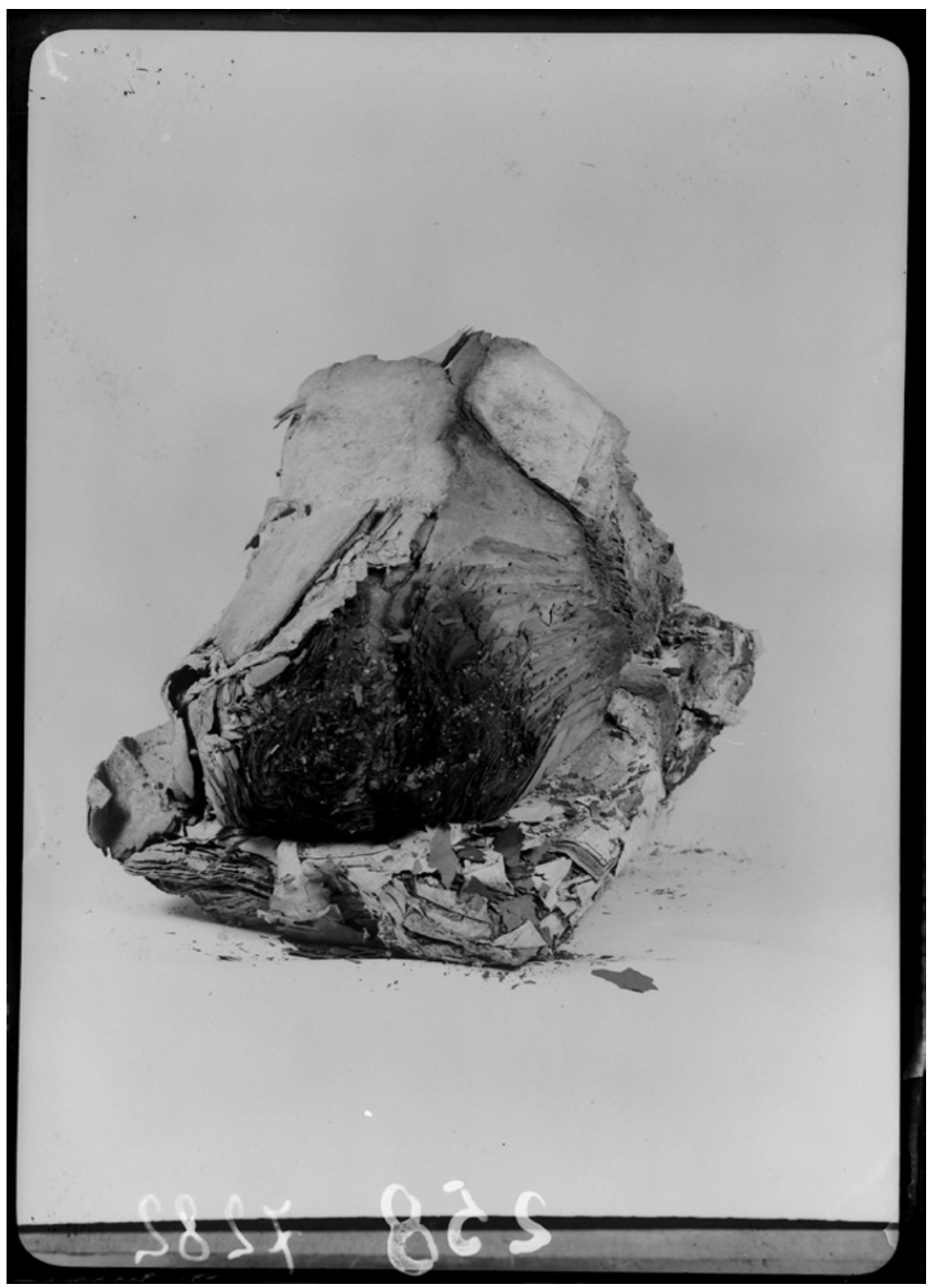

ILLUSTRATION 23.1 Book of the State Archive of Palermo burnt and extracted from rubble after the bombing of April 1943

(C) Istituto centrale per la patologia del libro, Rome [AF IST 258] 


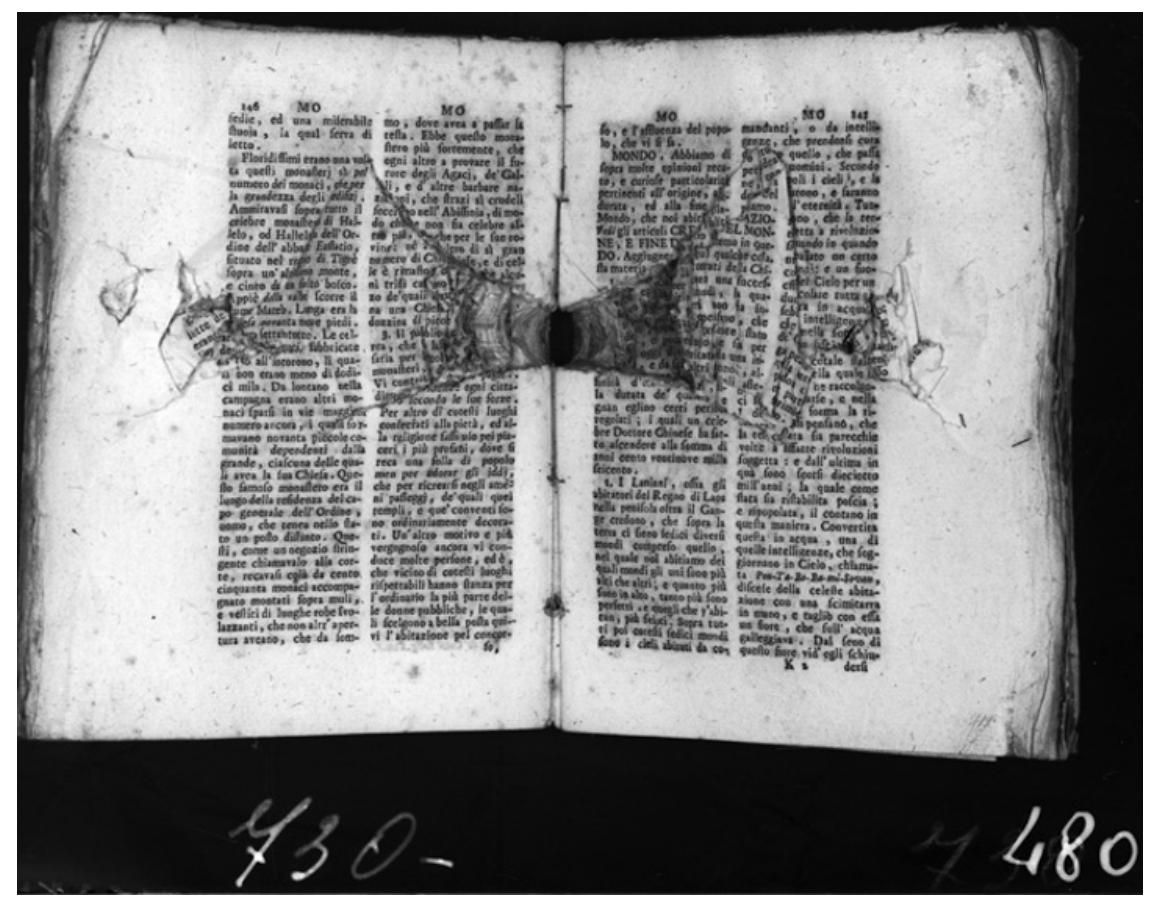

ILLUSTRATION 23.2 Book damaged by a bullet

(C) Istituto centrale per la patologia del libro, Rome [AF IST 480]

Working to this template, for each region a first table details the damage suffered by walls, windows, services, scaffolding, furniture and other objects; a second table shows the information available on the conditions of manuscripts, incunabula, sixteenth-century books, other printed books, miscellanies, bindings, collections and catalogues. The number of items that had been lost or damaged in each group is followed by its evaluation in the monetary value of $1945^{-46}$. Despite post-war devaluation, these reports were vital to help in planning rescue and reconstruction.

According to the tables at the end of the volume, the war caused the loss of some 38,700 manuscripts and documents, 376 incunabula, about 16,300 sixteenthcentury books and almost 2,000,00o later printed books in 315 Italian institutions. To these numbers we should add 33,631 manuscripts and documents, 298 incunabula, 2,315 sixteenth-century books and almost 400,000 other printed books damaged in libraries that were not included in the Ministry survey. The damage to buildings and furniture was estimated at roughly 2,000,00o Italian lira. ${ }^{5}$

5 La ricostruzione delle biblioteche italiane dopo la guerra 1940-45. I. I danni, pp. 344-347 and Andrea Paoli, «Salviamo la creatura». Protezione e difesa delle biblioteche italiane nella 
The reliability of these figures was discussed some sixty years later in a conference in Perugia in 2005, whose proceedings are available in a volume of 21 essays. ${ }^{6} \mathrm{~A}$ few case-histories expose the limits of the data collected immediately after the war and show that the effectiveness of the preservation operations had been grossly overestimated. In the case-study on the libraries of Genoa the contemporary evaluation needs to be raised by $60 \%$, or some 200,000 volumes, to reflect actual losses. ${ }^{7}$ Still, the original reports offer an interesting starting point to compare Italian policies for the preservation of cultural heritage before and after the second world war with those of other European countries.

From as early as 1934, in the perspective of an impending war, the Italian Ministry of Education began to develop a plan for the protection of library staff, users, buildings and collections. ${ }^{8}$ Between 1935 and 1936 the DirectorateGeneral of Academies and Libraries issued some comprehensive guidelines focused on the selection of books to safeguard. These were based on the division of assets into three classes prior to evacuation. Manuscripts, incunabula and exceptionally rare books were classified as objects of extraordinary cultural significance (class A). These had to be evacuated from the main urban centres, likely to be targets of air attacks, to isolated buildings believed to be secure, such as castles and monasteries in the countryside. A second class of books (B) comprised works of art and scholarship also valuable, like sixteenthcentury books, just not as rare as those of the first class. These should be moved to protected rooms likely in the basement of their usual building. A third class (C) of more recent and less valuable books would remain in its usual location. ${ }^{9}$ This would avoid the possible damage to civilian morale caused by a complete

seconda guerra mondiale (Rome: Associazione Italiana Biblioteche, 2003), p. 123 and table at p. 134; Andrea Paoli, 'I piani di protezione: la loro esecuzione', in Capaccioni, Paoli and Ranieri (eds.), Le biblioteche e gli archivi, pp. 33-97, pp. 92-94. Paoli, in his note 104 at p. 94, invites us to read the official reports with caution as they did not include all the libraries.

6 Capaccioni, Paoli and Ranieri (eds.), Le biblioteche e gli archivi.

7 Alberto Petrucciani, 'Studi di caso: Genova', in Capaccioni, Paoli and Ranieri (eds.), Le biblioteche e gli archivi, pp. 371-391, p. 389 .

8 See Mauro Guerrini in his Preface to Paoli, «Salviamo la creatura», p. 8; and ibid., p. 13.

9 La ricostruzione delle biblioteche italiane dopo la guerra 1940-45. I. I danni, pp. 11-13. See also Flavia Cristiano, 'I piani di protezione: le origini', in Capaccioni, Paoli and Ranieri (eds.), Le biblioteche e gli archivi, pp. 1-32, pp. 15-17 and 20-21; and Nicola Schneider, 'The Losses of the Music Collection of the Hessische Landesbibliothek in Darmstadt in 1944: A Case Study on the Failure to Safeguard Historical Library Holdings', in Anja-Silvia Goeing, Anthony Grafton, Paul Michel and Adam Blauhut (eds.), Collectors' Knowledge: What is Kept, What is Discarded (Leiden: Brill, 2013), pp. 381-414, at p. 383. For a detailed list of shelters and the collections 
evacuation of libraries before the start of the war. ${ }^{10} \mathrm{~A}$ substantial part of the collections remained available to users even in wartime, balancing the needs of preservation and continuing access to resources at least in the main public libraries. ${ }^{11}$ From 1942-43 the Vatican took charge of safeguarding operations for ecclesiastic archives and libraries ensuring their protection on site or arranging for their temporary storage in the Vatican. ${ }^{12}$

The evacuation of works of art and books had already taken place in Italy during the first world war. A selection of valuable items had been moved from Veneto and Friuli to Florence. A few manuscripts of the Marciana had found their shelter just beside the Laurentian library, in the crypt of the Medici Chapels. ${ }^{13}$ These rudimentary wartime plans were also useful inasmuch as they demonstrated the need for more accurate guidelines for heritage preservation. Shortly after the end of the war the Ministry of Education established in 1919 the Soprintendenze bibliografiche, local offices in charge of protection and supervision of book heritage for each region, and in 1926 the Direzione Generale Accademie e Biblioteche [Directorate-General of Academies and Libraries]. ${ }^{14}$

Scholars who have studied the question agree that Italian wartime measures for the protection of cultural heritage were well-advanced when compared to other European countries. This prevented the impact of war on archives and libraries from being as destructive as it could have been - and as it actually was

they would respectively host, see La ricostruzione delle biblioteche italiane dopo la guerra 1940-45. I. I danni, 'Misure preventive per la tutela del materiale librario', pp. 13-14; Andrea Paoli, 'I piani di protezione: la loro esecuzione', in Capaccioni, Paoli and Ranieri (eds.), Le biblioteche e gli archivi, pp. 33-97, at pp. 45-46; and Paoli, «Salviamo la creatura», pp. $18-45$.

10 This was indeed the argument against evacuation in British libraries: Paoli, «Salviamo la creatura», p. 144.

11 Petrucciani, 'Le biblioteche italiane durante la guerra'. See also Cristiano, 'I piani di protezione', pp. 18-19; and Paoli, «Salviamo la creatura», pp. 112-114 and 117.

12 Rapporto finale sugli Archivi, pp. 10-12; Massimo Ceresa, 'La Biblioteca Vaticana e le biblioteche romane durante la seconda guerra mondiale', in Capaccioni, Paoli and Ranieri (eds.), Le biblioteche e gli archivi, pp. 343-369, p. 345.

13 Cristiano, 'I piani di protezione', pp. 5 and 9-10; Simonetta Buttò, 'I bibliotecari italiani e la seconda guerra mondiale: generazioni a confronto', in Capaccioni, Paoli and Ranieri (eds.), Le biblioteche e gli archivi, pp. 249-277, pp. 257-259.

14 Roncuzzi Roversi Monaco, 'La tutela del patrimonio librario', at p. 87; Cristiano, 'I piani di protezione', p. 14; see also the introduction in Capaccioni, Paoli and Ranieri (eds.), Le biblioteche e gli archivi, pp. i-xxxvii, p. vii. Nine Soprintendenze archivistiche would only follow in 1939, too late to have a real role in wartime policies: see Rapporto finale sugli Archivi, p. 8. 
in some other parts of Europe. ${ }^{15}$ This was for several reasons. The so-called 'elastic defence' of taking decisions and moving material on the spot when events became too unpredictable worked well in the last phase of the war; ${ }^{16}$ the support of the Vatican in hosting books and archives not only from ecclesiastical institution from $1944 ;{ }^{17}$ lastly, a considerable contribution to the satisfactory outcome of preservation plans must be attributed to the personal commitment and exemplary dedication, nearly heroic, of several resolute Italian librarians and archivists. ${ }^{18}$

The fascist policy of centralisation also determined a consistent line of management for archives and libraries, balancing many centuries of fragmentation of the Italian states. The official plans for archival protection were similar to those for libraries and bibliographic material. ${ }^{19}$ By contrast, evacuations of German libraries appear occasional and uncoordinated, mostly entrusted to individual directors of libraries in the absence of any central authority in charge of this task. A lively debate brought Italy and France to similar decisions about safety measures for books and documents a few years before the outbreak of the war. In both countries these priorities were based on the selection of books to evacuate to protect them from aerial attacks. ${ }^{20}$ In Germany the first official statement concerned with the protection of libraries was only issued in June 1939 and was a verbatim translation of the Italian circular issued in December 1936 on the division of assets into three classes. Also differently from Italy, archives and libraries were not treated consistently. German archives depended on the Interior Ministry and their evacuation was organised centrally, making their situation slightly better than that of libraries. Such national policies were the results of diverse experiences: Italy planned wartime measures carefully in

15 See Rapporto finale sugli Archivi, pp. 8-9, 67-75; Paoli, «Salviamo la creatura», pp. 121 and 130-149, esp. p. 148; Ranieri, 'Il ruolo degli alleati', p. 172; Buttò, 'I bibliotecari italiani', pp. 249-250; Ceresa, 'La Biblioteca Vaticana e le biblioteche romane', pp. 343 and 354.

16 La ricostruzione delle biblioteche italiane dopo la guerra 1940-45. I. I danni, p. 18; Paoli, «Salviamo la creatura», p. 131; Paoli, 'I piani di protezione', pp. 76, 78 and 96; Ceresa, 'La Biblioteca Vaticana e le biblioteche romane', p. 343 .

17 Ceresa, 'La Biblioteca Vaticana e le biblioteche romane', pp. 343-349; Paoli, 'I piani di protezione', p. 76.

18 Paoli, «Salviamo la creatura», p. 50 passim, esp. p. 133; Paoli, 'I piani di protezione', p. 97; Buttò, 'I bibliotecari italiani'; Ceresa, 'La Biblioteca Vaticana e le biblioteche romane', pp. 343-344 and 349-350.

19 Rapporto finale sugli Archivi, pp. 7-8; Cristiano, 'I piani di protezione', p. 14 and 17-18; and Schneider, 'The Losses of the Music Collection', p. 382.

20 Paoli, «Salviamo la creatura», p. 145. The rules on the management of refuges were similar. 
advance in the anticipation of a new conflict, potentially more destructive than the war just recently fought out on her soil. Germany lacked recent experience as a battlefield and underestimated modern aerial warfare. ${ }^{21}$

This was actually a common mistake, partly shared by the Italian institutions as well. Despite a general awareness of the need to preserve buildings and collections from aerial attacks, the plans for protection were inappropriate to the emergencies of modern aerial warfare. ${ }^{22}$ The sixteenth-century building of the Archiginnasio in Bologna was only secured through fire safety measures, which would prove totally inadequate against aerial bombing. ${ }^{23}$ Nevertheless, the Italian plans for protection of books proved reasonably appropriate to the task, especially as evacuation was planned so much in advance. ${ }^{24}$

The selection of material actually took longer than the two months expected, and the evacuation of Italian state libraries took place in June 1940. ${ }^{25}$ About 200,000 volumes were moved to the identified shelters in about 4,400 crates. ${ }^{26}$ In autumn 1942 Allied bombings of Genoa, Turin and Milan encouraged a second round of evacuation. This would also include books of class B and, noteworthy, catalogues, as they might prove essential after the war to document any losses and to help the reconstruction. Conducted in a state of emergency, this second phase of evacuation was completed by August 1943. The crates almost doubled the quantity in the shelters. ${ }^{27}$ Evacuation of archives took place from 1941 to 1943 on the basis of similar criteria for the selection of material. ${ }^{28}$

21 Schneider, 'The Losses of the Music Collection', pp. 382-383; see also the article by Jan L. Alessandrini in this volume, esp. note 18.

22 Paoli, «Salviamo la creatura», pp. 15-17; Petrucciani, 'Le biblioteche italiane durante la guerra', p. 114, note 19 .

23 Valeria Roncuzzi Roversi Monaco, 'L'Archiginnasio bombardato: i danni all'edificio e al patrimonio librario', in Capaccioni, Paoli and Ranieri (eds.), Le biblioteche e gli archivi, pp. 535-545, at pp. 535-536; Roncuzzi Roversi Monaco, 'La tutela del patrimonio librario', pp. 93-95; Paoli, «Salviamo la creatura», pp. 130-131.

24 Paoli, 'I piani di protezione', p. 95; Paoli, «Salviamo la creatura», p. 132.

25 La ricostruzione delle biblioteche italiane dopo la guerra 1940-45. I. I danni, 'Misure preventive per la tutela del materiale librario', p. 13; Paoli, «Salviamo la creatura», pp. 23-26.

26 See the introduction in Capaccioni, Paoli and Ranieri (eds.), Le biblioteche e gli archivi, p. ix.

27 La ricostruzione delle biblioteche italiane dopo la guerra 1940-45. I. I danni, 'Misure preventive per la tutela del materiale librario', pp. 15-16; Paoli, «Salviamo la creatura», pp. 32-44; Paoli, 'I piani di protezione', pp. 66-69.

28 Rapporto finale sugli Archivi, pp. 9 and 13. 
Evacuation would prove vital for the library of the Archiginnasio in Bologna. Due to its position as a strategic railway node, Bologna was targeted by more than 90 bombings between 1943 and $1945 .{ }^{29}$ The Archiginnasio, built in the sixteenth century as the main hall of the University, was bombed in January 1944. Following the stipulated instructions, the most valuable items of the collections had been removed to Torrechiara in 1940 . Some more books and catalogues were brought in 1943 to the summer camp of Casaglia. Despite the destruction of both the building of the Archiginnasio and, by a twist of fate, that of Casaglia, the collections suffered some considerable losses but eventually a decent proportion would survive the war. ${ }^{30}$

Some spoilage was even caused by the unforeseen conditions to which evacuated materials were exposed in the refuges. $3^{2}$ crates of books of the Biblioteca Labronica of Leghorn were flooded by a tributary of the Arno while stored in the chartreuse of Calci in October $1945 .{ }^{31}$ The shelters were equipped to some extent against damp, animals and other possible hostile agents, but it was not enough to turn such makeshift accommodations into long-term convenient repositories for books and archival folders. The warm and dry Italian summer climate assisted evacuation in June 1940, but adverse weather conditions during the rest of the year proved detrimental for books. ${ }^{32}$ Another weakness of the Italian plans was the accumulation of collections from different libraries in the same refuge, as they could overload the buildings and would all be destroyed in the unfortunate case of a raid. In 1942 the abbey of Torrechiara, in Emilia, hosted books from up to eight libraries simultaneously. ${ }^{33}$

29 See the dedicated pages on the website of the Comune di Bologna by the Istituzione Bologna Musei and the library of the Archiginnasio, with extensive information, digitised newspapers and other resources: <http://memoriadibologna.comune.bologna.it/bombardamenti-aerei -subiti-da-bologna-95-evento > and <http://badigit.comune.bologna.it/bolognabombardata/ index.html>.

30 Roncuzzi Roversi Monaco, 'L'Archiginnasio bombardato'; Roncuzzi Roversi Monaco, 'La tutela del patrimonio librario'; Valeria Roncuzzi Roversi Monaco, 'Il bombardamento sull'Archiginnasio: vicissitudini dell'edificio storico e del patrimonio librario', in Cristina Bersani and Valeria Roncuzzi Roversi Monaco (eds.), Delenda Bononia: immagini dei bombardamenti 1943-1945 (Bologna: Pàtron, 1995), pp. 119-144; Petrucciani, 'Le biblioteche italiane durante la guerra', pp. 117-118; Paoli, «Salviamo la creatura», p. 112.

31 Paoli, «Salviamo la creatura», p. 102.

32 Rapporto finale sugli Archivi, pp. 10 and 49; La ricostruzione delle biblioteche italiane dopo la guerra 1940-45. I. I danni, pp. 14-15. See also, for instance, Roncuzzi Roversi Monaco, 'La tutela del patrimonio librario', pp. 95-96; Paoli, 'I piani di protezione', pp. 40, 56-66; and the quotation from Riccardo Filangieri below, pp. 480-481.

Paoli, 'I piani di protezione', p. 64 and 91, note 93. 
Despite a few accidents, wartime plans worked fairly well until 1943. In July 1943 the Allied landing in Sicily changed the dynamics of the war. On 3 September 1943, General Badoglio signed an armistice with the Allies, marking the exit of Italy from the Axis. In his proclamation on 8 September 1943, Badoglio stated that, after the requested armistice had been granted by General Eisenhower, commander-in-chief of the Anglo-American Allied forces, "all acts of hostility against the Anglo-American force by Italian forces must cease everywhere. But they may react to eventual attacks from any other source". ${ }^{34}$ This unexpected change of front would reveal previous wartime measures as myopic and tragically out of date. From September 1943, danger was suddenly not coming from aerial attacks anymore, but from German troops retreating up the boot of Italy. ${ }^{35}$

In October 1943 the German military government founded the Abteilung Kunstschutz bei bevollmächtigen General der deutschen Wehrmacht in Italien [usually simply called Kunstschutz], an office formally charged with preserving Italian monuments and works of art. This unit was placed under the direction of the German art historian Hans-Gerhard Evers from the University of Munich. ${ }^{36}$ Some steps toward an international agreement on heritage preservation during wartime had already appeared in the proceedings of the conferences of the Hague of 1899 and 1907, but they were valid only for signatory countries and mostly intended to protect works of art, leaving unclear what had to be preserved, and how, in archives and libraries. ${ }^{37}$ More critically, they were subject to 'military necessity'; and the contingency of aerial attacks was not even taken into consideration. The peace treaties after the first world war included some additional principles on heritage preservation, notably that of

34 The audio file of the speech, in Italian, read by Pietro Badoglio on the Ente Italiano per le Audizioni Radiofoniche (EIAR) on 8 September 1943 is available online on the RAI Radiotelevisione Italiana - website: <http://www.rai.tv/dl/RaiTV/programmi/media/ ContentItem-779832fd-4b38-4666-993e-fa7507fb2e96.html>. Italics mine.

35 Paoli, «Salviamo la creatura», pp. 46-76 and 98-99: 'Il fronte attraversa l'Italia: 1943'; Paoli, 'I piani di protezione', pp. 74-92.

36 Rapporto finale sugli Archivi, p. 12; Lutz Klinkhammer, 'Tra furto e tutela. Le biblioteche nel quadro dell'occupazione tedesca dell'Italia (1943-45)', in Capaccioni, Paoli and Ranieri (eds.), Le biblioteche e gliarchivi, pp. 143-165, at pp.147-148. On the work of the Kunstschutz see also Paoli, «Salviamo la creatura», p. 59; and Paoli, 'I piani di protezione', p. 79.

37 This vagueness was already highlighted in the Rapporto finale sugli Archivi, p. 7. Rosenne Shabtai (ed.), The Hague Peace Conferences of 1899 and 1907 and International Arbitration. Reports and Documents (The Hague: T.M.C. Asser, 2001); James Brown Scott (ed.), The proceedings of the Hague peace conferences: translation of the official texts prepared in the Division of international law of the Carnegie endowment for international peace (New York: Oxford University Press, 1920-1921). 
restitution. The destruction of Louvain in 1914 reinforced the idea that museums, archives, libraries and 'artistic towns' should somehow be protected from massive destruction. ${ }^{38}$ Despite never being formalised, this suggestion still had some influence during the second world war, especially for places such as Rome, Florence and Venice. ${ }^{39}$ On the other hand, this fostered the expectation that armies would avoid deliberately targeting works or cities of art, which turned out to be dramatically misleading. The conventional sign on the roofs of the most important libraries to help identifying historical and artistic buildings was mostly ignored. ${ }^{40}$

After the Allied landing in 1943 the commission for Monuments, Fine Arts and Archives [MFA\&A] was also involved in the management of the Italian heritage, from 1944 also including archives and libraries. The protection of the Italian heritage from the Nazis was a crucial point in the anti-German propaganda. Interestingly, this actually reacted to the German and fascist argument depicting the Allies as destroyers themselves. ${ }^{41}$ It should be noted that an interest in the archives was dictated by other needs alongside propaganda:

For what concerns papers (archives) and books, it must be considered that even those not looking very old might be of great importance, not only from a historical point of view but because they can contain useful information for actual war purposes. ${ }^{42}$

Unfortunately, all this was not enough to prevent pillage and destruction. Antisemitism encouraged the plunder of books and works of art from Jewish collections. This was also the fate of the two Jewish libraries in Rome, that of the Italian Rabbinical College and the Jewish Community of Rome. ${ }^{43}$ In

38 Schneider, 'The Losses of the Music Collection', p. 382.

39 See the introduction in Capaccioni, Paoli and Ranieri (eds.), Le biblioteche e gli archivi, pp. ii-v; Cristiano, 'I piani di protezione', pp. 4-5 and 26-29; Paoli, 'I piani di protezione', pp. 76 and 80.

40 Roncuzzi Roversi Monaco, 'La tutela del patrimonio librario', p. 92; Paoli, 'I piani di protezione', p. 95 .

41 Ruggero Ranieri, 'Il ruolo degli alleati nella preservazione delle biblioteche e degli archivi durante l'esperienza di liberazione/occupazione (1943-46)', in Capaccioni, Paoli and Ranieri (eds.), Le biblioteche e gli archivi, pp. 167-209, esp. pp. 182-185; Paoli, «Salviamo la creatura», pp. 57-58 and 96; Klinkhammer, 'Tra furto e tutela', pp. 148-152.

42 Allied instructions on the Archives, Administrative instruction no. 10 (30 March 1944), reiterated in the Memorandum of 6 December 1944 and in that of 3 April 1945: see Rapporto finale sugli Archivi, pp. 52-53.

Klinkhammer, 'Tra furto e tutela', pp. 158-159. 
December 1943 the library of the Rabbinical College was taken to Frankfurt am Main. It was returned to the College by the us Army after the war. There was no happy ending though for the library of the Community of Rome. This inestimable collection of some 7,00o books, including manuscripts and rare editions printed by Soncino, Bomberg, Bragadin and Giustiniani, is still lost. A Commission for the recovery of the bibliographic patrimony of the Jewish Community of Rome stolen by the Nazis in 1943 was set up under the Presidency of the Italian Council of Ministers in 2002. The Commission, made up of historians and archivists as well as high-ranking government officials, completed its mandate in 2009. ${ }^{44}$ In the final report, the Commission expressed the hope that

the data obtained may in the future be integrated with other data, found by others, perhaps through the exploration of the Russian archives today inaccessible, and that this might lead to the discovery of an invaluable cultural heritage. It is still the Commission's conviction that it cannot have utterly vanished. 45

After the armistice, the isolated shelters in the countryside where collections had been taken to save them from aerial attacks suddenly turned into unprotected places. Recalled by directors, the crates of books and documents made their way back to urban centres, believed to be more secure after the change of circumstances. ${ }^{46}$ Books that had been hosted in the abbey of Montecassino had providentially returned to Rome between December 1943 and January 1944 just before the abbey was razed by the Allies, persuaded it was a German stronghold, in February $1944 .{ }^{47}$ Three months later, Allied bombs destroyed part of the monastery of Santa Scolastica in Subiaco, including the rooms where crates with books had been stored in 1940. By then, they were safely back in Rome, hosted by the Vatican. ${ }^{48}$

The burning of the documents of the State Archive of Naples is a well-known example of a tragedy that could not be predicted inasmuch it was caused by

44 See the official translation (Oct. 2010) of the final report (Feb. 2009) on the activities of the Commission for recovery of the bibliographic patrimony of the Jewish community of Rome stolen in 1943, available online: <http://www.governo.it/Presidenza/USRI/confessioni/doc/ rapporto_finale_eng.pdf>.

45 Ibid., p. 6.

46 Rapporto finale sugli Archivi, pp. 9-10; Paoli, «Salviamo la creatura», pp. 47-49; Paoli, 'I piani di protezione', pp. 74-92.

47 Paoli, «Salviamo la creatura», pp. 57-6o and 95-96.

48 Paoli, «Salviamo la creatura», pp. 6o-73; Ceresa, 'La Biblioteca Vaticana e le biblioteche romane', pp. $353-354$. 
reprisal and not military strategy. German soldiers took Hitler's order to reduce Naples "to mud and ashes" literally. The core of the University founded by Frederick II in the thirteenth century, one of the oldest in Europe, was set on fire. 200,000 volumes, 3,000 folders, 200 bindings, 1,500 maps and 250 coins of the library of the Accademia Pontaniana and of the Royal Society of Science, Letters and Fine Arts of Naples were incinerated. ${ }^{49}$ The Archive was vandalised by the retreating German army as it left the city in late September 1943. After surviving many heavy bombings of the town, 866 crates containing over 30,000 volumes and 50,00o documents that had been moved to Villa Montesano near San Paolo Bel Sito for security reasons were destroyed. ${ }^{50}$ The State Archive preserved valuable documents from the period of Arabic, Norman, Imperial, French and Spanish domination of Naples. Amongst the losses were fourteenthand fifteenth-century papers from the Angevin-Aragonese period and the register of Frederick II dating from the years 1239-1240. ${ }^{51}$

The case of Naples offers a number of examples of successful initiatives to rescue and restore damaged or even lost heritage with various techniques. Already in 1935 Riccardo Filangieri, Superintendent of the Napolitan provinces and then Director of the State Archives, had raised his voice against the relocation of documents to the countryside, being aware of at least some of the dangers:

la mole considerevole, anche delle sole scritture più preziose, la difficoltà di un trasporto improvviso e quella di trovare un luogo sicuro da tutti i pericoli ai quali vanno soggette le scritture, specie l'incendio e l'umidità, consigliano di pensare e preparare entro le stesse mura di questo vasto edificio un ricovero ben munito da ogni pericolo di un trasloco di emergenza;

[the considerable quantity, even only of the most valuable documents; the difficulty of an unexpected move; and that of finding a safe place where

49 See Vincenzo Trombetta, 'Biblioteche e archivi napoletani durante la guerra', in Capaccioni, Paoli and Ranieri (eds.), Le biblioteche e gli archivi, pp. 393-442, pp. 408-411.

5o Riccardo Filangieri, 'Relazione sulla distruzione del deposito dei documenti di maggiore pregio storico dell'Archivio di Stato di Napoli operata dai tedeschi il 30 settembre 1943', in Rapporto finale sugli Archivi, pp. 54-57.

$5^{1}$ Cristina Carbonetti Vendittelli, 'Cancelleria, Registro della (1239-1240)', in Enciclopedia Treccani, available online: < http://www.treccani.it/enciclopedia/registro-della-canceller ia_\%28Federiciana\%29/>. The register was made of paper: some mandates of the imperial court of Frederick II from the years 1228-1230 are amongst the oldest examples of the use of paper in a chancellery: see Giulio Battelli, Lezioni di paleografia (Vatican: Scuola Vaticana di Paleografia e Diplomatica, 1949), p. 34; and Bernhard Bischoff, Paleografia latina (Padova: Antenore, 1992), p. 15. 
papers would not be damaged, especially by fire and damp, would suggest careful reflection and the establishment of a shelter right inside this vast building, well equipped against any risk of an emergency move $]{ }^{52}$

The news of the destruction of the Neapolitan Archives would have sounded dreadfully bitter to his ears; still he did not give up. Immediately after the war, Filangieri established an office to work on the reconstruction of the content of the documents destroyed in 1943 from sources such as microfilms, photographic reproductions and transcriptions either published or collected by scholars at various times. ${ }^{53}$ This enormous enterprise, initially seen by contemporaries as hopeless, was eventually taken over by the Accademia Pontaniana of Naples and has produced fifty volumes so far. ${ }^{54}$ The project started by Filangieri is now going through a new, digital stage. In 2001, the University of Naples launched a research project to convert the volumes into an online textual database. Between 2001 and 2008, a purpose-made PHP script converted semi-automatically the text of six volumes into 4,839 records. The work is still in progress and another 4,00o records will be added soon to the online database..$^{55}$ The aim of the project is to enhance access to the data through an index and a custom-made search-engine. In a second stage, sources that are not included in the printed volumes will be also digitised and added to

52 Quoted in Trombetta, 'Biblioteche e archivi napoletani', p. 411, note 32.

53 The Ufficio della ricostruzione angioina started its work in 1944. See Guido Fagioli Vercellone, 'Filangieri di Candida Gonzaga, Riccardo', in Dizionario Biografico degli Italiani, vol. 47 (1997), available online: <http://www.treccani.it/enciclopedia/filangieri -di-candida-gonzaga-riccardo_\%28Dizionario-Biografico\%29/>.

54 Riccardo Filangieri etc. (eds.), I registri della Cancelleria Angioina (Naples: Accademia Pontaniana, 1949-). The 5oth volume has been edited by Stefano Palmieri and published in 2010. After an attempts at discouraging Filangieri from undertaking such a challenge, Benedetto Croce was eventually persuaded of its significance and it was he who proposed the volumes to the Accademia Pontaniana for publication: "L'impresa si presentava ardua, sì che quando esposi il mio intento al venerato mio amico Benedetto Croce, egli in un primo momento non lo credette attuabile, avendone nel suo alto sapere subito intuite le molteplici e non lievi difficoltà. Ma poi, avendo voluto io tentarne un saggio, lo stesso Croce finì per credervi, ed a tal segno che propose egli stesso all'Accademia Pontaniana la pubblicazione dei registri ricostruiti, proposta che...è da vari anni in atto": see Carlo Giglio and Marco Mozzati (eds.), Inventario delle fonti manoscritte relative alla storia dell'Africa del nord esistenti in Italia, vol. 3: Teobaldo Filesi (ed.), Gli archivi pubblici della Campania e in particolare l'Archivio di Stato di Napoli dalle origini al 1922 (Leiden: Brill, 1973), p. 57 .

I am grateful to Alfredo Cosco for this information. 
the database. ${ }^{56}$ An edition of the lost register of Frederick II similarly based on photos, abstracts and transcriptions from the original was published in 2002. ${ }^{57}$

Images were a distinctive trait of fascist cultural policy and propaganda. Documenting the present through pictures and videos was the purpose of the Istituto Nazionale Luce, founded between 1924 and $1925 .{ }^{58}$ As seen above, the care of cultural heritage played a significant part in propaganda before and during the war. In 1940 the Ministry of Education invited library directors and superintendents to take photos of preservation operations, of the shelters, inside and outside, and of the opening of the crates of books returned to libraries after the war. ${ }^{59}$

The production of photographic documentation was amongst the main functions of the Istituto Centrale di Patologia del Libro [Central Institute for Pathology of the Book], another instance of Italian excellence in the field of book preservation in the first half of the twentieth century. In 1938 Alfonso Gallo, who had also worked on the official plans for preservation between 1934 and $1939,{ }^{60}$ submitted a proposal to the Ministry of Education to create an institute for the study of the book through techniques and methodologies from both scientific and historical knowledge. The plan was supported by the minister of Education Giuseppe Bottai, who shortly after proposed a law on

$5^{6}$ The project Il Regno angioino (secoliXIII-XV) is directed by Roberto delle Donne and technically managed by Alfredo Cosco, Paolo Di Vece and Manuela Schiano: $<$ http://www .cdlstoria.unina.it/storia/angio/>; the index of the registers is available here: <http:// www.cdlstoria.unina.it/storia/angio/registri/toc.php >.

57 Cristina Carbonetti Vendittelli (ed.), Il Registro della Cancelleria di Federico II del 1239-1240 (Rome: Istituto Storico Italiano per il Medioevo, 2002).

58 Gian Piero Brunetta, 'Istituto nazionale L.U.C.E.', in Enciclopedia del Cinema Treccani (2003), available online: <http://www.treccani.it/enciclopedia/istituto-nazionale-l-u-c -e_\%28Enciclopedia-del-Cinema\%29/>; Antonia Liguori, Luce su Littoria 1932-1944. Aspetti sociali della bonifica nell'Agro pontino (Latina: Ali di Pan, 2013), 'Il volto della propaganda attraverso la "pupilla" del Regime', pp. 161-163; Antonia Liguori, 'L'occhio del regime sulla Grande guerra: l'Istituto Luce tra informazione, memoria e propaganda', Dimensioni e problemi della ricerca storica, 2003, 2, pp. 109-146.

59 Roncuzzi Roversi Monaco, 'La tutela del patrimonio librario', p. 90.

6o Eliana Fileri, 'Gallo, Alfonso', in Dizionario Biografico degli Italiani, vol. 51 (1998), available online: <http://www.treccani.it/enciclopedia/alfonso-gallo_\%28Dizionario-Biograf ico\%29/>; Giorgio de Gregori, 'Gallo, Alfonso', in Giorgio de Gregori and Simonetta Buttò, Per una storia dei bibliotecari italiani del XX secolo: dizionario bio-bibliografico 1900-199o (Roma: Associazione Italiana Biblioteche, 1999), pp. 95-96, available online: <http:// www.aib.it/aib/editoria/dbbi2o/gallo.htm>; Cristiano, 'I piani di protezione', pp. 15 and 24-26; Paoli, 'I piani di protezione', pp. 44-45; Paoli, «Salviamo la creatura», pp. 16 and 150; Ceresa, 'La Biblioteca Vaticana e le biblioteche romane', p. 347 and 360. 
the "safeguarding of items of historical and artistic interest". ${ }^{61}$ In Gallo's intention, the institute would mainly work on the restoration of books damaged by war or other accidents. ${ }^{62}$

The Institute had an essential role in the restoration of books harmed in major disasters such as the second world war and the great flood of Florence in 1966; but it also has a more long-term significance as a resource for information on the book as a material and historical object. Since its foundation, the Institute is also home to a museum of conservation "arranged to represent the wide range of causes of damage to library heritage", measures for prevention and restoration. ${ }^{63}$ In 2007 it was merged with the Centre of Photo-reproduction, Bindery and Restoration for the State Archives to become the new Central Institute for the Restoration and Preservation of Archival and Book Heritage. ${ }^{64}$ A photographic archive comprising 8,000 plates and 27,000 diapositives and available online through the Institute's website provides detailed pictures of the restoration work carried out in the Institute from 1938 (ills. 23.3, 23.4, 23.5 and 23.6). ${ }^{65}$

Without underestimating the impact of the second world war on Italian archives and libraries, ${ }^{66}$ it is a widely-shared opinion that damage and losses look limited in Italy in comparison with those suffered by other European countries, despite heavy bombardment and three years of war fought on her soil. ${ }^{67}$ The most valuable items of state libraries were saved, with the sole exception of 2,80o manuscripts and documents of the abbey of Montecassino. Most of the libraries that experienced considerable losses were not state libraries. These 'other' institutions (private, ecclesiastical, local public libraries) complied with the suggestion of Superintendents to move or evacuate books only in small

$61 \quad$ Law no. 1089 (1939). See the publication at the next note for further details.

62 Mauro Brunello, Laura Ciancio, Paola F. Munafò, Flavia Pinzari and Maria Luisa Riccardi, Istituto Centrale di Patologia del Libro. A Guide to the Museum (Rome: Istituto Centrale di Patologia del Libro, 2004), p. 7. The Institute remained under Gallo's direction until his death in 1952.

63 Brunello, Ciancio, Munafò, Pinzari and Riccardi, Istituto Centrale di Patologia del Libro, pp. 7-9; quotation at p. 8 .

64 See the website of the Institute: <http://www.icpal.beniculturali.it/storia_e_finalita .html $>$. An English version of the page is forthcoming.

65 <http://www.icpal.beniculturali.it/fotografico.html>. The archive also includes photos of its own labs, tools and materials, plus pictures of damaged or restored books and of libraries in Italy and abroad.

66 Schneider points up that "it is clear from the official post-war reports that around 80 per cent of the state libraries were heavily damaged in Italy as well" ("The Losses of the Music Collection', p. 382, note 6).

67 See above, note 15 . 


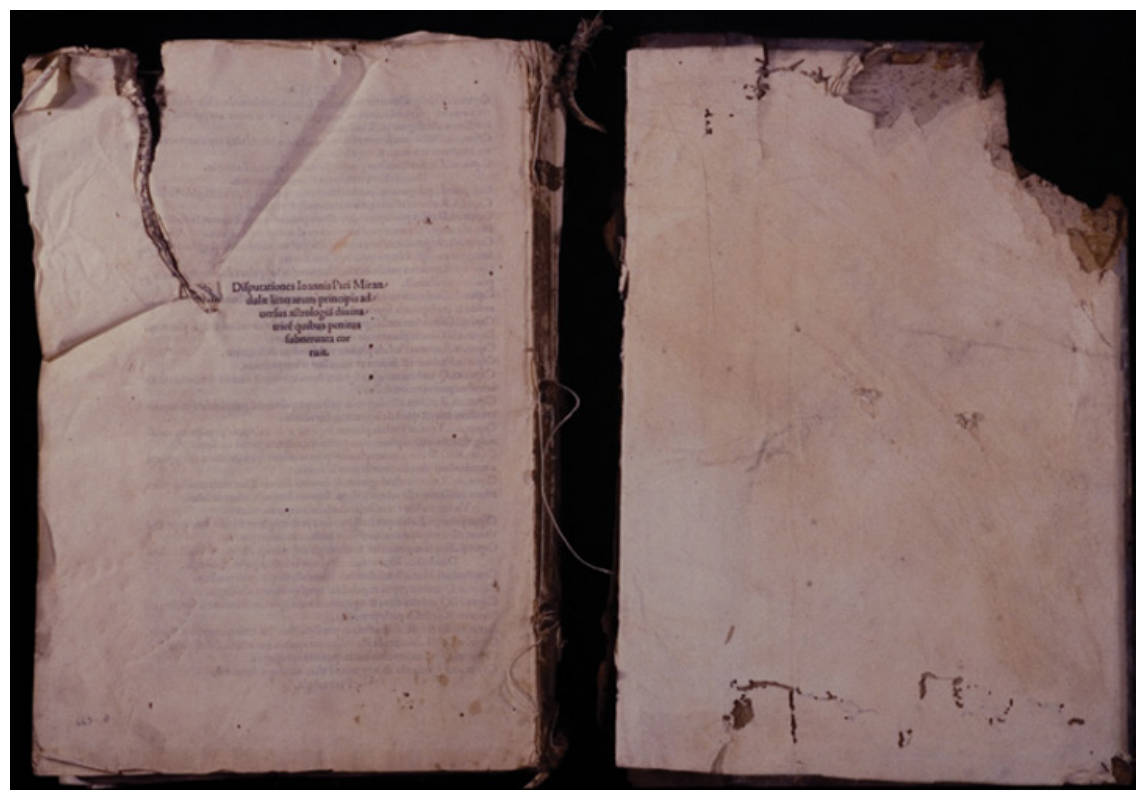

illustration 23.3 Picus de Mirandula, Opera (Venice: Bernardinus Venetus de Vitalibus, 1498), copy of the Biblioteca del Seminario vescovile, Verona [Giul. 347], final leaf and rear board before restoration

(C) Istituto centrale per la patologia del libro, Rome [AF DIA 05213]

quantities, especially as they were requested to do so at their own expenses. ${ }^{68}$ This proves that a clear and centralised policy for the management of archives and libraries in each country and international agreements are both essential for the preservation of cultural heritage not only in exceptional wartime circumstances. Italian evacuation plans also show a praiseworthy awareness of the relevance of catalogues that might prove fundamental in the process of identification of lost or found books, to support their restitution and to prove their existence in the event of massive destruction. This concern for an accurate catalogue should not to be forgotten in peacetime. Similarly, reproductions might prove crucial as well to document any damage and loss, even if they will obviously never be meant to replace the originals. This point should be highlighted in the debate on digitisation and preservation of digital objects.

Books and documents can be seriously damaged or lost not only as a result of dramatic events. To remain on Italian soil, in 2014-15 the Italian

68 La ricostruzione delle biblioteche italiane dopo la guerra 1940-45. I. I danni, pp. 14-15. See also Paoli, 'I piani di protezione', pp. 55-56 and 93-94; and Paoli, «Salviamo la creatura», p. 122. 


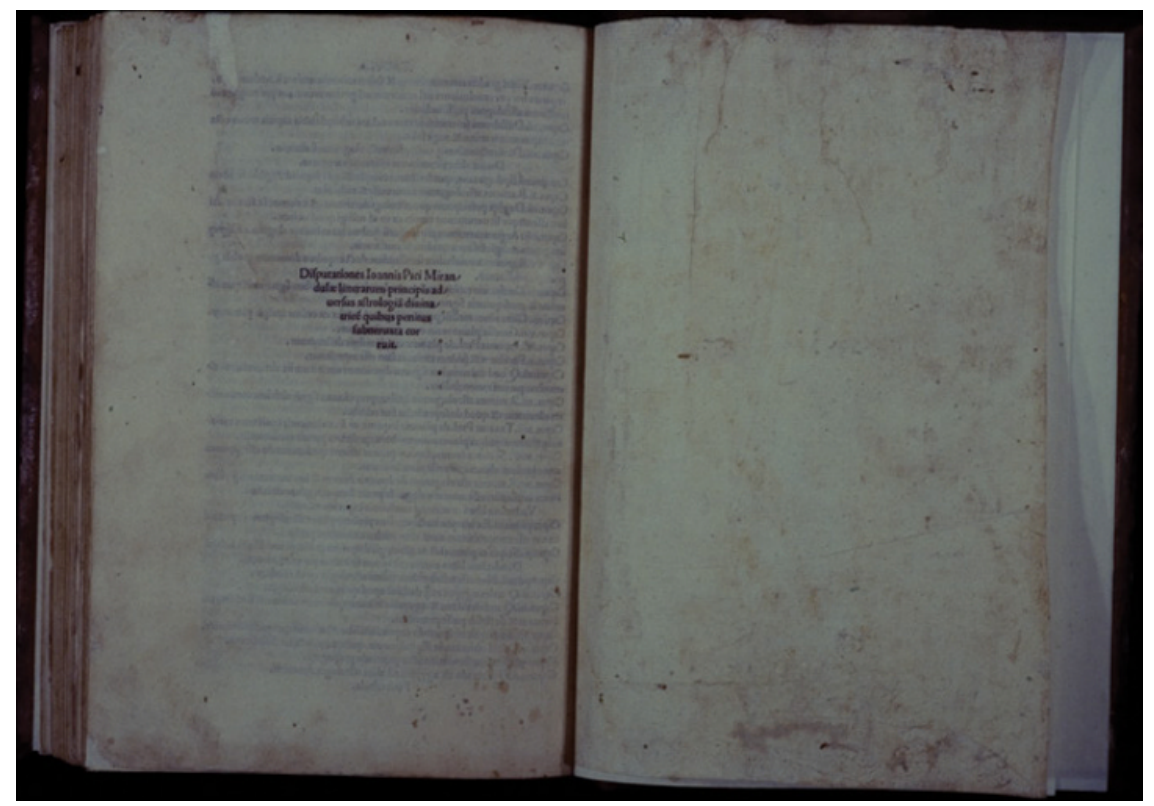

illustration 23.4 Picus de Mirandula, Opera (Venice: Bernardinus Venetus de Vitalibus, 1498), copy of the Biblioteca del Seminario vescovile, Verona [Giul. 347], final leaf and rear board after restoration

(C) Istituto centrale per la patologia del libro, Rome [AF DIA 07982]

Directorate-General in charge of national archives sponsored, with the contribution of the Regione Sardegna, the restoration of 6oo linear metres of documents of the Società Bonifiche Sarde dating from 1912 to 1989 . Despite their significance for the history of twentieth-century Sardinia, the documents were in a deplorable state of conservation, precluding consultation and putting their own survival at risk. ${ }^{69}$

Some international projects provide support for the preservation of archives under the threats of war or other circumstances. In 1992 UNESCO established the Memory of the World Programme to encourage preservation and photographic or digital reproduction of endangered documentary heritage. ${ }^{70}$ The Endangered Archives Programme of the British Library offers annual grants for

69 The folders are now hosted in the State Archive of Oristano. Some impressive pictures of the documents in their collocation before and after the restoration are available online on the website of the Soprintendenza Archivistica per la Sardegna: <http://www.sa-sardegna .beniculturali.it/index.php?it/191/archivio-sbs-avviato-il-recupero $>$.

70 See the website of the programme: $<$ http://www.unesco.org/new/en/communicationand-information/flagship-project-activities/memory-of-the-world/homepage/>. 


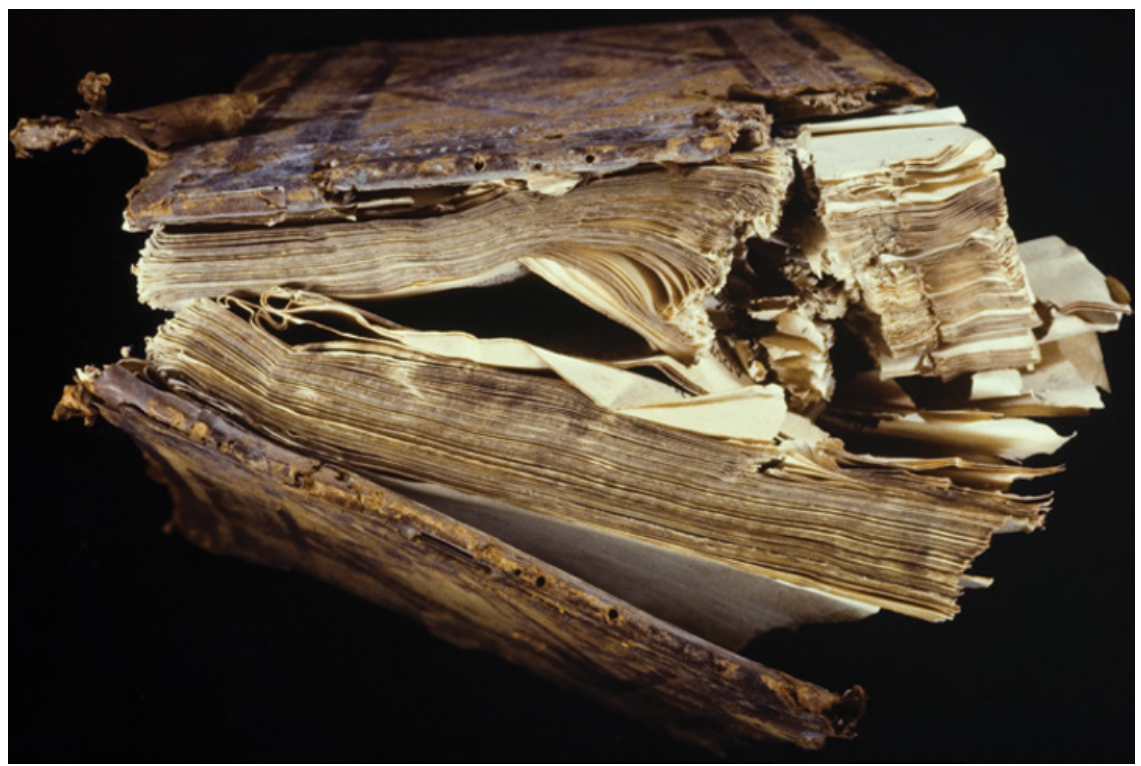

illustration 23.5 Picus de Mirandula, Opera (Venice: Bernardinus Venetus de Vitalibus, 1498), copy of the Biblioteca del Seminario vescovile, Verona [Giul. 347], top edge before restoration

(C) Istituto centrale per la patologia del libro, Rome [AF DIA 07220]

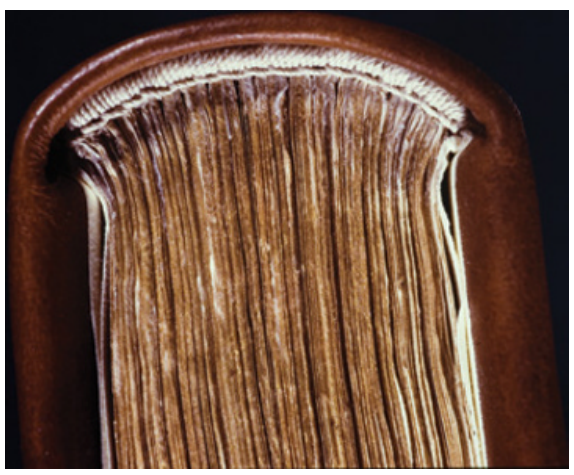

ILLUSTRATION 23.6

Picus de Mirandula, Opera (Venice:

Bernardinus Venetus de Vitalibus, 1498), copy of the Biblioteca del Seminario vescovile, Verona [Giul. 347], headband after restoration

(C) Istituto centrale per la patologia del libro, Rome [AF DIA 07984]

the preservation of archival material that is in danger of destruction, neglect or physical deterioration world-wide. ... The grants provide funding to enable successful applicants to locate relevant endangered archival collections, to arrange their transfer to a suitable local archival home 
where possible, to create digital copies of the material and to deposit the copies with local institutions and the British Library. ${ }^{71}$

Similarly, in 2015 the International Federation of Library Associations and Institutions [IFLA] has created a Risk Register for Documentary Cultural Heritage

in order to raise awareness for the preservation, conservation, and safeguarding of documentary heritage (in any format) world-wide. We aim to gather data on documentary heritage collections in order to be able to respond adequately if confronted with natural or man-made disasters. ${ }^{72}$

Some recent or forthcoming conferences confirm a growing interest in the topic, partly stimulated by alarming contingencies such as the Glasgow School of Art fire of 2014 or the burning of the manuscripts of Timbuktu in 2013. ${ }^{73}$ These are positive signs that new policies for the protection of documentary and library heritage may emerge soon in each country and in an international framework. Nonetheless, the development of a shared awareness of the sense of cultural roots, either in a national or world perspective, is still the biggest challenge in the struggle for the preservation of memory.

71 See the website of the programme: <http://eap.bl.uk>, especially the page on The Threat to Archives (<http://eap.bl.uk/pages/threat.html>), and Maja Kominko (ed.), From Dust to Digital: Ten Years of the Endangered Archives Programme (Cambridge: Open Book Publishers, 2015).

72 See $<$ http://www.ifla.org/risk-register $>$ and the news about its launch at the IFLA annual conference: $<$ http://www.ifla.org/node/9754>.

73 To mention just a few: What do we lose when we lose a library? - International Conference, Leuven, 9 September 2015, University Louvain-La Neuve \& KU Leuven, programme available online: <https://kuleuvencongres.be/libconf2015/website/program>; Fire in the Archives: Experiences Shared, Lessons Learned - Preservation Committee Event and scA Annual Members Meeting, Edinburgh, 30 September 2015, programme available online: $<$ http://www.scottisharchives.org.uk/fire >. 